\title{
The Organo-Zeolitic-Soil System: A Comprehensive Fertilizer
}

\author{
Peter J Leggo* \\ Department of Earth Sciences, University of Cambridge, UK
}

*Corresponding author: Peter J Leggo, Department of Earth Sciences, University of Cambridge, UK, Tel: +01223 333 462; E-mail: pj146@cam.ac.uk

Received date: March 20, 2014; Accepted date: August 12, 2014; Published date: August 20, 2014

Copyright: ( 2014 Leggo PJ, et al. This is an open-access article distributed under the terms of the Creative Commons Attribution License, which permits unrestricted use, distribution, and reproduction in any medium, provided the original author and source are credited.

\section{Short Communication}

Highly contaminated mine and refinery metal waste sites can remain barren of vegetation for many years. In some cases the only solution has been to bury it in a landfill site, but it is more desirable to regenerate the land. A new strategy of soil amendment to greatly enhance the scope of plant growth on damaged and marginal soils has been developed. A critical factor is how to supply sufficient plant nutrients to sustain growth. Organo-zeolitic biofertilizer answers this question as unlike synthetic chemicals, it provides a natural source of plant nutrients by greatly increasing the population of soil nitrifying micro-organisms.

The use of chemical fertilizers, over the last sixty or more years, has been of great benefit in keeping world food crop supply ahead of population growth. However, this achievement has not been without a cost to soil health and the environment, as it is now known that without a regular input of organic matter $(\mathrm{OM})$ the over use of nitrogen, phosphorus, potassium (NPK) fertilizers causes nutrient limited microbes to rapidly decomposes the soil OM which, in time, can lead to a structure-less soil with less capacity to hold water; causing greater runoff and groundwater pollution [1]. In addition to the high energy costs of the Haber-Bosch process for producing ammonia from atmospheric nitrogen the source of natural phosphate is becoming less readily available. The organo-zeolitic biofertilizer does not suffer the disadvantages of the conventional NPK fertilizers in being potentially less expensive, particularly in countries that have zeolitic tuff resources, easier to produce in terms of energy costs and of greater benefit to soil health.

In earlier work it was discovered that zeolitic tuff, containing an abundance of clinoptilolite, was very effective in the removal of ammonium ions from secondary effluent and the application to water and wastewater treatment has been studied in considerable detail [2]. This work focuses attention on the highly selective ion-exchange behaviour of natural zeolites for ammonium ions. Further, work on the removal of ammonium ions from municipal wastewater showed that an increase in nitrate occurred in the treated water which was indicative of biological activity. This earlier work has lead to a working hypothesis based on new empirical date, which proposes that by mixing crushed zeolitic tuff with organic waste ammonium ions, from the decomposing organic matter, are ion-exchanged into the zeolite lattice $[3,4]$. When this mixture (the biofertilizer) is added to a plant substrate, contaminated or otherwise, it would appear that the ammonium ions are slowly back exchanged by soil potassium after which ammonium oxidizing micro-organisms initiate nitrification with the effect of producing luxuriant growth and high plant quality.

What limited work that has been done on the chemical analysis of plant shoots has shown that the uptake of an adequate supply of major, minor and beneficial trace elements occurs [5]. The analytical results of this study show large differences in uptake between plants grown in substrates with and without the biofertilizer amendment. Both Brassica napus (Oil Seed Rape) and Salix viminalis (Osier Willow) showed these differences. As a very large growth enhancement is always seen in those plants grown in substrates amended with the biofertilizer it would appear logical to conclude that homeostasis is playing a major role and that the nutrient uptake is controlled by this behaviour.

Recent research in the Cambridge laboratory has been directed towards the identification of the microbial organisms that cause the nitrification in the biofertilizer amended substrates. A time-course experiment was made to observe populations of ammonium oxidizing bacteria and/or archaeal prokaryotes using B. napus in plant pots. A local sandy soil low in plant nutrents was used as a substrate. This substrate was amended with the biofertilizer and manure was used as a control in the same ratio of amendment to soil. Using molecular biological methods three species of ammonium oxidizing Crenarchaeota have been discovered. Dilutions of the extracted soil DNA were used as templates in polymerase chain reactions (PCR) using primers targeted to conserve portions of the ammonia oxidizing genes [6]. It is interesting to note that no bacterial nitrifiers have, so far, been found. This feature is consistent with other work that finds that prokaryotes from the kingdom Archea, the Crenarchae, are now known to be commonly occurring soil nitrifying micro-organisms and that Archaea predominate among ammonia-oxidizing prokaryotes in soils [7].

It is now clear that use of the biofertilizer will allow marginal land, as well as waste sites, to be cultivated in many parts of the World. Those countries that have suitable zeolitic tuff resources will be in a position to make the biofertilizer at far less expense than importing chemical fertilizers. The application rate of the biofertilizer depends on the soil and plant type involved and this, at present, is still undergoing development.

\section{References:}

1. Uphoff NT (2006) Energy Inputs in Soil Systems. Biological Approaches to Sustainable Soil Systems. Taylor \& Francis, New York, 79-89.

2. Kalló D (2001) Application of Natural Zeolites in water and wastewater treatment. Reviews in Mineralogy and Geochemistry 45: 519-550.

3. Semmens MJ, Wang JT, Booth AC (1977) Nitrogen removal by ionexchange biological regeneration of clinoptilolite. J Water Poll Cont Fed 49: 2431-2444

4. Murphy CB, Hrycyk O, Gleason WT (1978) Natural zeolite : Novel uses and regeneration in wastewater treatment. Natural zeolites: Occurrence, Properties, Use, Pergamon Oxford UK, 451-462.

5. Leggo PJ, Ledésert B, Day J (2010) Organo-zeolitic treatment of mine waste to enhance the growth of vegetation. Eur J Mineral 22: 813-822.

6. Hansel CM, Fendorf S, Jardine PM, Francis FA (2008) Changes in Bacterial and Archaeal Community Structure and Functional Diversity along a Geochemically Variable Soil Profile. Appl Envirn Microbiol 74: 1620-1633. 
Citation: Leggo PJ (2014) The Organo-Zeolitic-Soil System: A Comprehensive Fertilizer. Int J Waste Resources 4: 156. doi: 10.4172/2252-5211.1000156

Page 2 of 2

7. Leininger S, Urich T, Schloter M, Schwark L, Qi J, et al. (2006) Archaea predominate among ammonia-oxidizing prokaryotes in soil. Nature 442: 806-809. 